\title{
The effects of salt stress on growth, nitrate reduction and proline and glycinebetaine accumulation in Prosopis alba
}

\author{
Diego Ariel Meloni ${ }^{1}$, Marta Rosalía Gulotta ${ }^{2}$, Carlos Alberto Martínez ${ }^{3^{*}}$ and Marco Antonio Oliva ${ }^{4}$
}

${ }^{1}$ Facultad de Agronomía y Agroindustrias, Universidad Nacional de Santiago del Estero, Av. Belgrano (S) 1912, 4200 - Santiago del Estero, Argentina; ${ }^{2}$ Facultad de Ciencias Forestales, Universidad Nacional de Santiago del Estero, Av. Belgrano (S) 1912, 4200- Santiago del Estero, Argentina; ${ }^{3}$ Departamento de Biologia, FFCLRP, Universidade de São Paulo, Av. Bandeirantes 3900, CEP 14040-901, Ribeirão Preto, São Paulo, Brasil; ${ }^{4}$ Departamento de Biologia Vegetal, Universidade Federal de Viçosa, CEP 36571-000 Viçosa, Minas Gerais, Brasil.*Corresponding author: carlosamh@ffclrp.usp.br

Received: 16/12/2003, Accepted:05/03/2004

Prosopis alba (algarrobo) is one of the most important salt-tolerant legumes used in the food and furniture industries. The effects of salinity on some growth and physiological parameters in algarrrobo seedlings were investigated. 17-Day-old seedlings were subjected to three salt treatments by adding $\mathrm{NaCl}$ to the growth medium in $50 \mathrm{mmol} . \mathrm{L}^{-1}$ increments every $24 \mathrm{~h}$ until the final concentrations of 0,300 and $600 \mathrm{mmol} . \mathrm{L}^{-1}$ were reached. Only the highest $\mathrm{NaCl}$ concentration affected all of the considered parameters. Thus, $600 \mathrm{mmol} . \mathrm{L}^{-1} \mathrm{NaCl}$ caused a significant reduction in root and shoot growth, but an increase in the root/shoot ratio. Leaf relative water content, nitrate content and nitrate reductase activity in leaves and roots were also decreased. At 300 and $600 \mathrm{mmol} . \mathrm{L}^{-1}$, the glycinebetaine content was significantly increased in both leaves and roots but this was not found for proline content. Total soluble carbohydrates increased only in roots. The results suggest that glycinebetaine enhancement may be important for osmotic adjustment in Prosopis alba under salinity stress.

Key words: glycinebetaine, nitrate reductase, proline, salinity.

Efeitos do estresse salino sobre o crescimento, redução do nitrato e acúmulo de glicinabetaína e prolina em Prosopis alba: Prosopis alba (algarrobo) é uma das mais importantes leguminosas arbóreas resistentes a estresse salino, utilizada como alimento, e na indústria de móveis. Neste trabalho, avaliaram-se os efeitos do estresse salino sobre alguns parâmetros fisiológicos em plântulas de algarrobo. Plântulas de 17 dias de idade foram submetidas a três tratamentos de estresse salino adicionando $\mathrm{NaCl}$ ao meio de crescimento com incrementos de 50 mmol.L $\mathrm{L}^{-1}$ de $\mathrm{NaCl}$ a cada $24 \mathrm{~h}$ até atingir as concentrações finais de 0 , 300 e 600 mmol.L $\mathrm{L}^{-1}$. Somente a elevada concentração de $\mathrm{NaCl}$ causou efeitos significativos nos parâmetros avaliados. Assim, uma redução significativa no crescimento de raízes e caules e um incremento da relação raízes/caules foram observados sob $600 \mathrm{mmol} . \mathrm{L}^{-1} \mathrm{NaCl}$. Por efeito da elevada concentração salina, houve também um decréscimo no conteúdo relativo de água em folhas e no conteúdo no nitrato e na atividade da redutase do nitrato em folhas e raízes. Sob 300 e 600 mmol.L-1 observou-se um incremento proporcional e significativo no conteúdo de glicinabetaína tanto em raízes como em folhas, mas esse fato não se verificou no conteúdo de prolina. Por efeito do estresse salino, o conteúdo de carboidratos solúveis totais incrementou somente em raízes. Esses resultados sugerem que o ajuste osmótico em Prosopis alba, sob estresse salino, estaria associado principalmente ao incremento de glicinabetaina.

Palavras-chave: glicinabetaina, prolina, redutase do nitrato, salinidade.

\section{INTRODUCTION}

Soil salinity, resulting from natural processes or from crop irrigation with saline water, occurs in many arid to semi-arid regions of the world (Lauchli and Epstein, 1990). According to Tanji (1990), 20\% of cultivated land worldwide is adversely affected by high salt concentration, which inhibits plant growth and yield. In warm and dry areas salt concentration increases in the upper soil layer due to high water losses which exceed precipitation (Ebert et al., 2002). Overcoming salt stress is a main issue in these regions to ensure agricultural sustainability and crop production. 
Algarrrobo (Prosopis alba) is a native legume from the semiarid regions of north- western Argentina. Locally it is called "the tree", because of its widespread occurrence and importance in providing nutritious pods suitable for human food and wood for the furniture industry (Felker et al., 2001). Compared with other forest species, algarrrobo is ranked as a very salt tolerant tree because it can grow at approximately seawater salinities (Rhodes and Felker, 1987; Velarde et al., 2003).

For overcoming salt stress, plants have evolved complex mechanisms that contribute to the adaptation to osmotic and ionic stress caused by high salinity. These mechanisms include osmotic adjustment that is usually accomplished by uptake of inorganic ions as well as the accumulation of compatible solutes (osmoprotectants). Inorganic ions are sequestered in the vacuoles (Binzel et al., 1988), while organic solutes are compartmentalized in the cytoplasm to balance the low osmotic potential in the vacuole (Rontein et al., 2002).

Osmoprotectants are small, electrically neutral molecules that are nontoxic at molar concentrations and stabilize proteins and membranes against the denaturating effect of high concentrations of salts and other harmful solutes (Munns, 2002). Moreover, natural osmoprotectant concentrations in cytoplasmic compartments are osmotically significant because they have pivotal roles in maintaining cell turgor and the driving gradient for water uptake under stress (Balibrea et al., 2000; Naidoo and Naidoo, 2001; Rontein et al., 2002). In plants, the major compatible osmoprotectant solutes are glycinebetaine, proline and polyols (Rontein et al., 2002). The osmoprotectant levels are typically highest during exposure to osmotic stress since accumulation is usually to some extent stress-induced (Bohnert et al., 1995). The contributory role of glycinebetaine to osmotic adjustment under salt stress was confirmed by several investigations (Khan et al., 1998; Yeo, 1998), but the significance of proline accumulation in osmotic adjustment is still debated and varies according to the species (Lutts et al., 1996, Meloni et al., 2001; Rhodes and Hanson, 1993).

Several biochemical processes are affected by salinity, particularly nitrate assimilation. Nitrate is the most significant source of nitrogen for crop plants, and frequently limits plant growth. It has been reported that nitrate uptake in several higher plants is mediated by different transport systems. A high affinity saturable system operates at low $\mathrm{NO}_{3}{ }^{-}$ concentrations, whereas a low affinity linear system operates at high $\mathrm{NO}_{3}{ }^{-}$concentrations (Cerezo et al., 1997). Nitrate reductase (NR, EC 1.6.6.1.) catalyzes the first step of nitrate assimilation in higher plants and algae, which appears to be a rate limiting process in the acquisition of nitrogen in most cases (Flores et al., 2002). Although the processes that involve nitrogen uptake and assimilation are well known, the information regarding the effects of salinity on them is limited and controversial (Viégas et al., 1999). Several studies have reported that nitrate uptake and nitrate reductase activity (NRA) decrease in plants under salt stress (Rao and Gnaham, 1990; Gouia et al., 1994). Other studies have reported NRA stimulation (Misra and Dwiverdi, 1990; Sagi et al., 1997).

The objective of this work was to evaluate the effects of high $\mathrm{NaCl}$ concentrations on algarrrobo seedlings to provide information on the significance of proline and glycinebetaine accumulation in response to salt stress and to determine the effects of salinity on growth and nitrate reduction.

\section{MATERIALS AND METHODS}

Plant material and growth condition: Seeds of algarrobo (Prosopis alba) were kindly provided by the Laboratory of Seed Analysis, National University of Santiago del Estero, Santiago del Estero, Argentina. Seeds were scarified to overcome hard seed coat dormancy by removing a small portion of the coat at the cotyledon end with nail clippers. Seeds were germinated on filter paper towels soaked with demineralized water. Six 7-day-old seedlings were transferred to $5 \mathrm{~L}$ growth containers filled with half-strength Hoagland solution (Hoagland and Arnon, 1950). Seedlings were grown in these conditions for $6 \mathrm{~d}$ before the initiation of $\mathrm{NaCl}$ treatments. $\mathrm{NaCl}$ was added to the growth medium in 50 mmol. $\mathrm{L}^{-1}$ increments every $24 \mathrm{~h}$, until the final concentrations of 0,300 and $600 \mathrm{mmol} . \mathrm{L}^{-1}$ were reached. Seedlings were illuminated continuously with fluorescent grolux lamps (100 $\left.\mu \mathrm{mol} . \mathrm{m}^{-2} \cdot \mathrm{s}^{-1}\right)$ in a growth room at $25 \pm 2^{\circ} \mathrm{C}$. The $\mathrm{pH}$ was maintained at 6.5 by adding solutions of $\mathrm{H}_{2} \mathrm{SO}_{4}$ or $\mathrm{KOH}$. After $30 \mathrm{~d}$ of salt treatment, the plants were harvested, measured and analyzed.

Growth measurement: Plant growth was estimated by measuring accumulation of root and shoot dry weight (after drying the plant material at $70^{\circ} \mathrm{C}$ for $48-72 \mathrm{~h}$ ).

Leaf relative water content: The leaf relative water content (RWC) was calculated according to Beadle et al. (1993) using the equation: RWC $(\%)=[(\mathrm{FW}-\mathrm{DW}) /(\mathrm{TW}-\mathrm{DW})] 100$, where FW is fresh weight, DW is dry weight, and TW is turgid weight.

Betaine, proline and total soluble carbohydrates contents: Betaine was extracted by stirring finely ground-dried samples with demineralized water at $100^{\circ} \mathrm{C}$ for one hour. Betaine 
content was determined spectrophotometrically after reaction with $\mathrm{KI}_{-} \mathrm{I}_{2}$ at $365 \mathrm{~nm}$ (Grieve and Grattan, 1983). Proline was also determined spectrophotometrically following the ninhydrin method described by Bates et al., (1973) using Lproline as a standard. Approximately $300 \mathrm{mg}$ of dry tissue was homogenized in $10 \mathrm{~mL}$ of $3 \%(\mathrm{w} / \mathrm{v})$ aqueous sulphosalicylic acid and filtered. To $2 \mathrm{~mL}$ of the filtrate, 2 $\mathrm{mL}$ of acid ninhydrin was added, followed by the addition of $2 \mathrm{~mL}$ of glacial acetic acid and boiling for $60 \mathrm{~min}$. The mixture was extracted with toluene, and the free proline was quantified spectrophotometrically at $520 \mathrm{~nm}$ from the organic phase using a Shimadzu spectrophotometer (Duisburg, Germany). Total soluble carbohydrates (TSC) concentration was determined according to Ciha and Brun (1978) with some modifications. Samples of $100 \mathrm{mg}$ were homogenized with $10 \mathrm{~mL}$ of extracting solution (glacial acetic acid: methanol: water, 1:4:5, v/v/v). The homogenate was centrifuged for 10 min at 3,000 rpm and the supernatant was decanted. The residue was resuspended in $10 \mathrm{~mL}$ of extracting solution and centrifuged another $5 \mathrm{~min}$ at 3,000 rpm. The supernatant was decanted, combined with the original extract and made up to $50 \mathrm{~mL}$ with water. For measurement of TSC, a phenol-sulfuric acid assay was used (Dubois et al., 1956). A volume of 0.5 $\mathrm{mL}$ of $5 \%(\mathrm{v} / \mathrm{v})$ phenol solution and $2.5 \mathrm{~mL}$ of concentrated sulfuric acid were added to $0.5 \mathrm{~mL}$ aliquots. The mixture was shaken, heated in a boiling water-bath for $20 \mathrm{~min}$ and cooled to room temperature. The absorption was then determined by spectrophotometry (Shimadzu spectrophotometer, Duisburg, Germany) at $490 \mathrm{~nm}$.

Nitrate concentration and in vivo nitrate reductase activity assay: For nitrate determinations, roots and leaves were dried at $70^{\circ} \mathrm{C}$ in an air-forced oven $48 \mathrm{~h}$, and ground to pass 40 mesh. Nitrate was determined by the method of Cataldo et al. (1975). Nitrate Redutase activity (NRA) was determined using the method described by Klepper et al. (1971) with some modifications. Approximately $100 \mathrm{mg}$ of $5 \mathrm{~mm}$ diameter leaf discs or $300 \mathrm{mg}$ of root segments $5 \mathrm{~mm}$ in length were vacuum infiltrated in $2 \mathrm{~mL}$ of incubation solution containing 0.1 mmol.L $\mathrm{L}^{-1}$ potassium phosphate buffer $\mathrm{pH} 7.5,0.05$ mol.L $\mathrm{L}^{-1}$ $\mathrm{KNO}_{3}$ and $1 \% \mathrm{v} / \mathrm{v}$ isopropanol. The incubation was conducted for $1 \mathrm{~h}$ at $30^{\circ} \mathrm{C}$ in the dark. To estimate the amount of nitrite formed, $1 \mathrm{~mL}$ each of $1 \%$ sulfanilamide in $1 \mathrm{mmol}^{-\mathrm{L}^{-1} \mathrm{HCl}}$ and $0.02 \%$ naphthylethylene diamine dihydrochloride were added and the test tubes vortexed. Absorbance of this resulting solution was recorded at $540 \mathrm{~nm}$ with a Shimadzu UV-VIS spectrophotometer (Shimadzu, Duisburg, Germany). Protein content was determined according to Bradford (1976) with bovine serum albumin as standard and NRA was expressed as $\mu \mathrm{mol} \mathrm{NO}_{2}^{-} \cdot \mathrm{mg}^{-1}$ protein.h-1.

Experimental design and statistical analysis: The experimental design was fully randomized with three replicates. Each flask containing six seedlings was considered as the experimental unit. All parameters were analyzed by analysis of variance (ANOVA). The means were compared by the Tukey test at a 0.05 confidence level. Relationship between nitrate concentration and NRA was determined by linear regression.

\section{RESULTS AND DISCUSSION}

Salinity caused a significant $(p<0.05)$ reduction on root and shoot dry biomass only at the higher $\mathrm{NaCl}$ concentration (Table 1). Increase in salinity from 0 to 300 mmol. $\mathrm{L}^{-1} \mathrm{NaCl}$ had no effect on plant biomass, while the further increase to $600 \mathrm{mmol} . \mathrm{L}^{-1} \mathrm{NaCl}$ significantly decreased shoot and root biomass by $65 \%$ and $37 \%$ respectively. The proportion of dry weight allocated to roots increased with increasing $\mathrm{NaCl}$ levels, as shown by the responses of root/shoot ratio (table 1). Previous studies carried out with cotton (Meloni et al., 2001), as well as in soybean and alfalfa (Berstein and Ogata, 1966; Kant et al., 1994) also showed that shoot growth was more inhibited by $\mathrm{NaCl}$ than root growth. Thus, increased root/ shoot ratio appears to be an adaptation to salinity, resulting in a more efficient water and nutrient uptake under saline stress (Gorham et al., 1985). Little work has been done on root physiology with regard to either salt or water stress (Munns, 2002). Roots would appear to be the most vulnerable part of the plant as they are directly exposed to salt or to drying soil, but nevertheless they are surprisingly robust. Our data show that root growth of algarrrobo plants, submitted to high $\mathrm{NaCl}$ concentrations, was not affected as much as shoot growth (table 1). According to Hsiao and $\mathrm{Xu}$ (2000), root growth, in contrast to leaf growth, recovers remarkably well from the addition of salt or other osmotica. In addition, visible senescence and necrosis symptoms were found on the basal, oldest leaf of young algarrrobo plants after $12 \mathrm{~d}$ of the 600 mmol. $\mathrm{L}^{-1} \mathrm{NaCl}$ treatment (data not shown). These symptoms could be a result of excess $\mathrm{Na}^{+}$and $\mathrm{Cl}^{-}$ions, which are known to induce chlorosis in Acacia nilotica subspecies (Nabil and Coudert, 1995). If excessive amounts of salt enter the plant they will eventually rise to toxic levels in the older transpiring leaves, causing premature senescence (Munns, 2002). 
Table 1. Effect of $\mathrm{NaCl}$ treatment on shoot and root dry weight and on the root/shoot ratio in algarrobo seedlings

\begin{tabular}{cccc}
\hline $\begin{array}{c}\mathrm{NaCl} \\
\left(\mathrm{mmol}^{-1} \mathrm{~L}^{-1}\right)\end{array}$ & $\begin{array}{c}\text { Dry Weight }(\mathrm{g})^{\mathrm{a}} \\
\text { Root }\end{array}$ & Root/ Shoot ratio \\
\hline 0 & $0.0227 \mathrm{a}$ & $0.0760 \mathrm{a}$ & $0.2981 \mathrm{a}$ \\
300 & $0.0196 \mathrm{a}$ & $0.0671 \mathrm{a}$ & $0.2927 \mathrm{a}$ \\
600 & $0.0142 \mathrm{~b}$ & $0.0269 \mathrm{~b}$ & $0.5260 \mathrm{~b}$ \\
\hline
\end{tabular}

${ }^{a}$ Means followed by the same letter in the column do not differ statistically at $\mathrm{p}<0.05$ (Tukey's test).

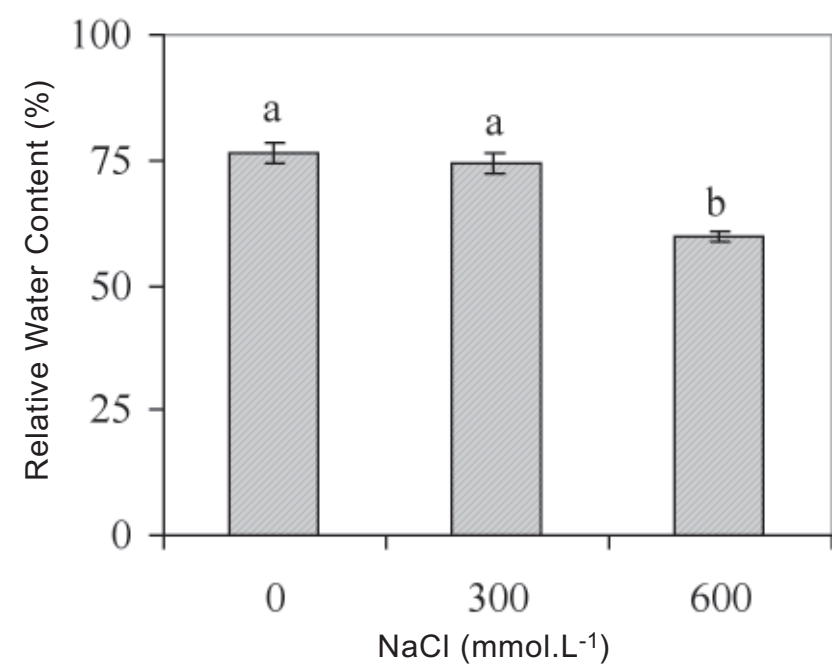

Figure 1. Effects of $\mathrm{NaCl}$ treatments on the relative water content in algarrobo seedlings. Bars followed by the same letter does not differ statistically at $\mathrm{p}<0.05$ (Tukey's Test). Averages of three determinations are presented with bars indicating SE.

At $300 \mathrm{mmol.L} \mathrm{L}^{-1} \mathrm{NaCl}$ seedlings were able to adjust osmotically, leading to a maintenance of relative water content (RWC), although at $600 \mathrm{mmol} . \mathrm{L}^{-1} \mathrm{NaCl}$, RWC was $11 \%$ lower than in the unsalinized control (figure 1).

The osmotic adjustment would be accomplished by the accumulation of organic solutes. Among the organic solutes investigated, glycinebetaine (GB) showed the highest absolute accumulation in response to salinity. In this regard, at 300 mmol. $\mathrm{L}^{-1} \mathrm{NaCl}$ the GB content increased 5-fold and 6.8-fold in roots and leaves, respectively, as compared with the control (figure 2A). Increase in salinity from 300 to $600 \mathrm{mmol.L}-1$ $\mathrm{NaCl}$ had no effect on the $\mathrm{GB}$ concentrations of roots or leaves. Accumulation of GB represents a major biochemical adaptation in several bacteria, plants and animals (Rhodes and Hanson, 1993). It has been demonstrated that the biosynthesis of GB is stress-inducible (Sakamoto and Murata, 2002) and that the level of accumulated GB is correlated with
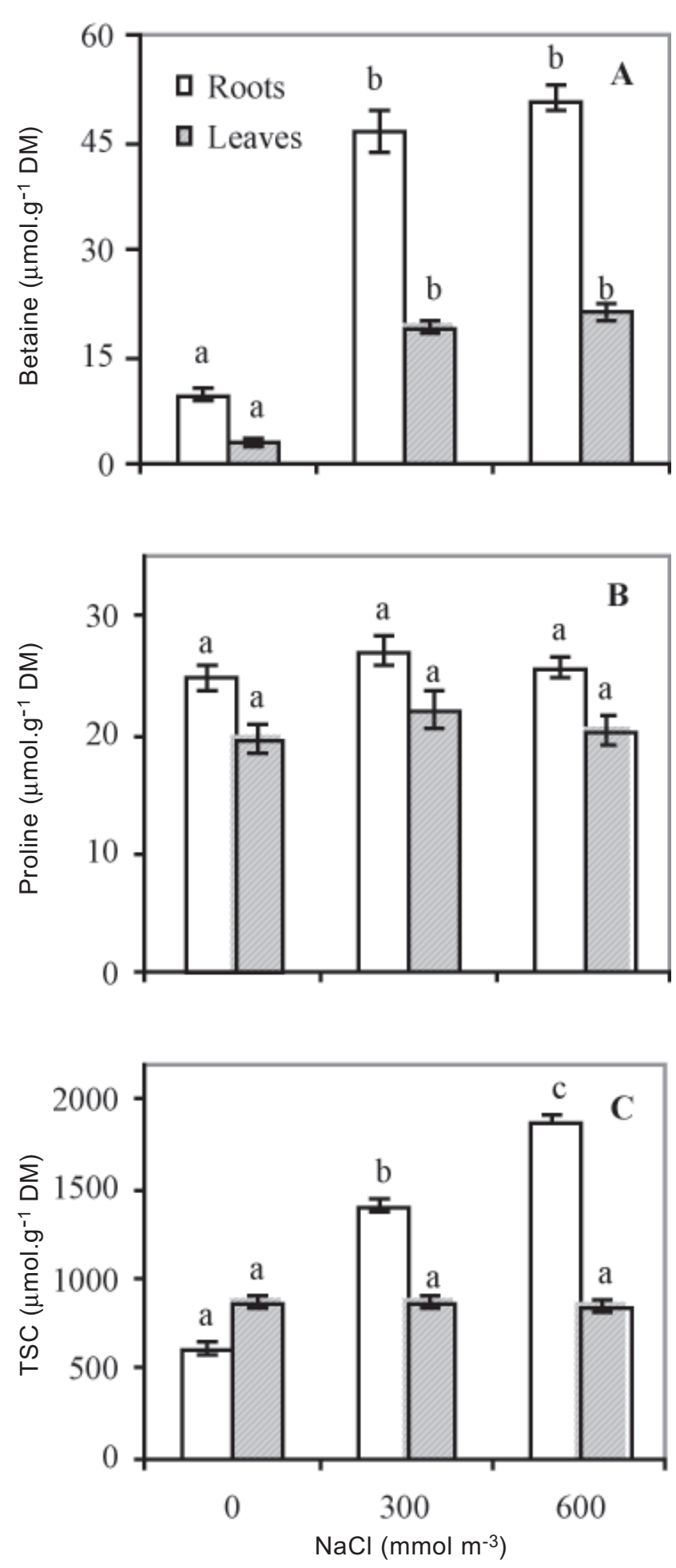

Figure 2. Effects of $\mathrm{NaCl}$ treatments on betaine (A), proline (B) and total soluble carbohydrates, TSC (C) concentrations in roots and leaves of algarrobo seedlings. Bars followed by the same letter for root or leaves does not differ statistically at $\mathrm{p}<0.05$ (Tukey's Test). Averages of three determinations are presented with bars indicating SE. 
the degree of salt tolerance (see for example Saneoka et al., 1995). Moreover, an exogenous supply of GB also increases the salt tolerance of some plants that are otherwise unable to accumulate GB (Hayashi et al., 1998). The responses of transgenic plants to stress demonstrated that genetic engineering of the synthesis of GB increased the ability of plants to tolerate a variety of environmental stresses, such as salt and extremes of temperature (Sakamoto and Murata, 2002). Although GB is accumulated in transgenic plants at low levels only, the extent of protection against a given stress is correlated with the level of accumulated GB (Sakamoto and Murata, 2001). In addition to its role as osmoprotectant, GB has been reported to protect the oxygen-evolving the PSII complex, stabilize the structure of extrinsic proteins of PSII complex, and ATP synthesis as well as protect cell membranes and activation of enzymes in onion and rice (Mansour, 1998; Rahman et al., 2002).
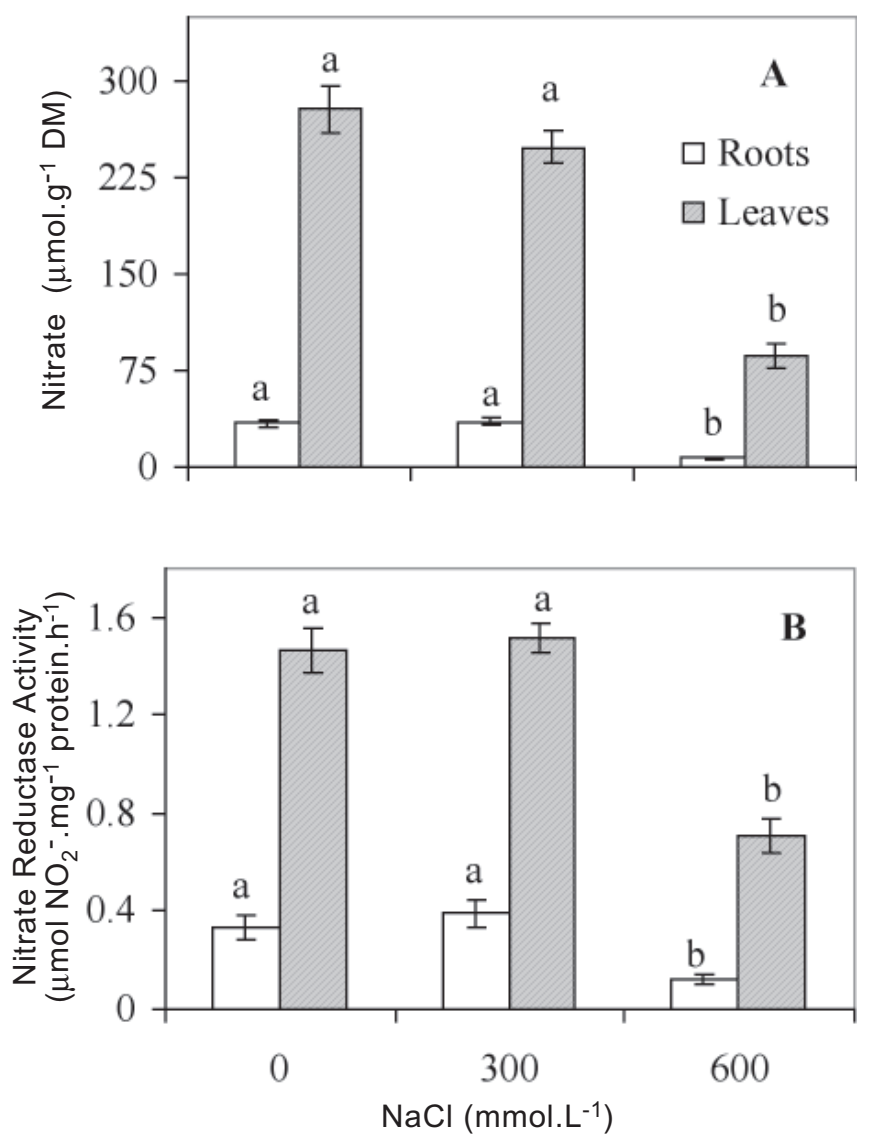

Figure 3. Effects of $\mathrm{NaCl}$ treatments on nitrate concentration (A) and nitrate reductase activity (B) in roots and leaves of algarrobo seedlings. Bars followed by the same letter for root or leaves does not differ statistically at $p<0.05$ (Tukey's Test). Averages of three determinations are presented with bars indicating SE.
Proline accumulation was not significantly affected by salinity (figure 2B). Contrary to its generally accepted role in many other species, proline does not seem to play an important role in the mechanism of salt tolerance in algarrrobo. The significance of proline accumulation in osmotic adjustment is still debated and varies according to the species. Ashraf (1989), Lutts et al. (1996), Feitosa de Lacerda et al. (2001) and Meloni et al. (2001) reported that proline is not involved in the osmotic adjustment of black gram, sorghum, rice and cotton cultivars, respectively. Recently, Heuer (2003) reported that proline was not able to counteract salt stress effects in salt-sensitive tomato plants.

Root total soluble carbohydrates (TSC) concentration increased sharply in relation to the stress intensity. With the increase in salinity to 300 and $600 \mathrm{mmol} . \mathrm{L}^{-1} \mathrm{NaCl}$, root TSC significantly increased by $230 \%$ and $309 \%$ respectively, compared with control (figure 2C). TSC concentrations in leaves were unaffected by salinity. Moreover, the salt stressed seedlings accumulated more total soluble carbohydrates in the roots than in the leaves, thus showing a change in behavior of shoot/root carbon partitioning. This probably reflects the maintenance or even induction of root elongation at low water potentials, which can be considered as an adaptive response to drought and salinity (Balibrea et al., 2000).

The nitrate concentration in roots and leaves was not influenced by 300 mmol.L $L^{-1} \mathrm{NaCl}$. At $600 \mathrm{mmol} . \mathrm{L}^{-1} \mathrm{NaCl}$, nitrate concentration in leaves was reduced by about $69 \%$ compared with the control. This salt effect was more drastic in the roots, which diminished by $78 \%$. (figure $3 \mathrm{~A}$ ). Salinity interferes with $\mathrm{N}$ acquisition and utilization. Saline conditions can influence the different steps of $\mathrm{N}$ metabolism, such as uptake, reduct ion and protein synthesis, that may be responsible, at least in part, for the observed reduction in plant growth rate (Frechill et al., 2001). Salinity affects nitrate uptake at two levels: by direct competition of chloride with nitrate and at the membrane level and/or the membrane proteins by changing plasmalemma integrity (Cramer et al., 1985).

In vivo nitrate NRA was considerably greater in leaves than in roots. As for nitrate concentration, NRA did not change with the $300 \mathrm{mmol} \cdot \mathrm{L}^{-1} \mathrm{NaCl}$ treatment (figure 3B). The addition of $600 \mathrm{mmol} . \mathrm{L}^{-1} \mathrm{NaCl}$ induced a substantial decline in NRA by about $64 \%$ in roots and $52 \%$ in leaves. On the other hand, a positive correlation was found between NRA and nitrate concentrations in leaves and roots (figures 4A and B). In this sense, cytosolic nitrate seems to protect the NR enzyme against the action of proteases and/or inhibitors besides triggering the de novo synthesis of NR 

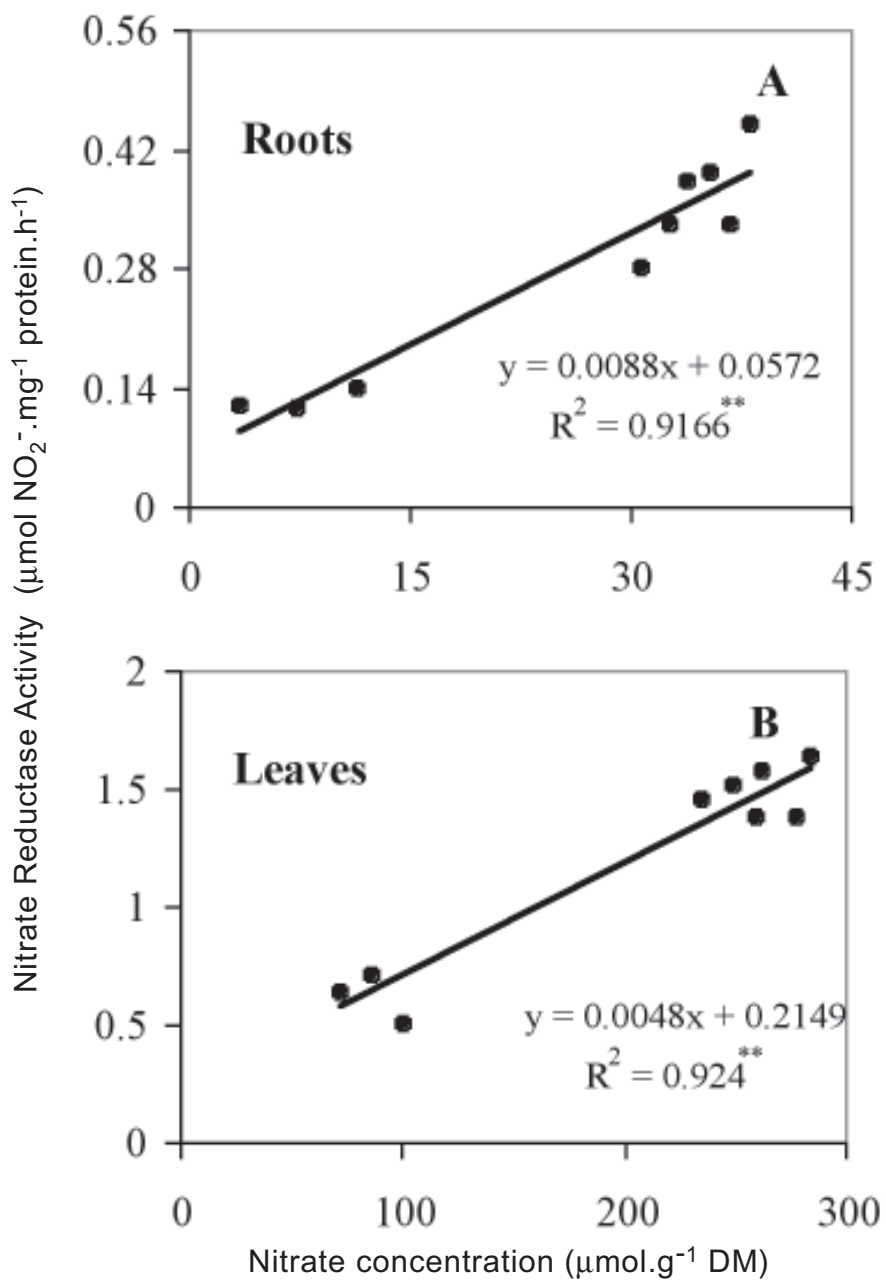

Figure 4. Relationships between nitrate reductase activity and nitrate concentrations in roots (A) and leaves (B) of algarrobo seedlings exposed to different salinity treatments.

protein by induction of NR gene expression (Campbell, 1999). Even so, under conditions of restricted nitrate flux induced by salt stress or water deficit, NRA could be lowered initially due to enzyme degradation/inactivation and the reduction in gene expression and NR protein synthesis (Ferrario et al., 1998). These changes in nitrate reduction were paralleled by those expressed by plant growth.

In agreement with observations of Silveira et al. (2001) for cowpea, algarrrobo plants subjected to $\mathrm{NaCl}$ stress presented a possible homeostasis between nitrate assimilation and plant growth. Even though the plants showed lower growth rates, they were compatible with the general processes of nitrate reduction. A similar coordinate balance between $\mathrm{C}$ and $\mathrm{N}$ assimilation was proposed for maize plants subjected to drought stress (Foyer et al., 1998).

In conclusion, algarrrobo seedlings can tolerate high salinity (up to $300 \mathrm{mmol} . \mathrm{L}^{-1} \mathrm{NaCl}$ ) in the root system, and probably adjust osmotically, through GB and soluble carbohydrate accumulation. At $600 \mathrm{mmol}^{-1} \mathrm{NaCl}$, a significant reduction in root and shoot growth occurred, but an increase in root/shoot ratio was observed. Leaf relative water content, nitrate content and nitrate reductase activity in leaves and roots were also decreased. The NRA decrease was largely dependent on nitrate concentration. Algarrrobo is a very interesting forest species, which can be used as a model to further the understanding of tree physiological responses to salinity.

Acknowledgements: The authors grateful to Mrs. Elba Bravo for her assistance. This study was supported by the Consejo de Investigaciones Científicas y Tecnológicas de la Universidad Nacional de Santiago del Estero, Argentina.

\section{REFERENCES}

Ashraf M (1989) The effect of $\mathrm{NaCl}$ on water relations, chlorophyll, and protein and proline contents of two cultivars of Black gram (Vigna mungo L.) Plant Soil 119:205-210.

Balibrea ME, Dell' Amico J, Bolarín MC, Perez-Alfocea F (2000) Carbon partitioning and sucrose metabolism in tomato plants growing under salinity. Physiol. Plant. 110:503-511.

Bates LS, Waldren RP, Tear ID (1973) Rapid determination of free proline for water stress studies. Plant Soil 39:205-207.

Beadle CL, Ludlow MM, Honeysett L (1993) Water relations. In: Hall DO, Scurlock JMO, Bolhàr-Nordenkampf HR, Leegood RC, Long SP (eds), Photosynthesis and Production in a Changing Environment, pp.113-127. Chapman \& Hall, London, England.

Berstein L, Ogata G (1966) Effects of salinity on nodulation, nitrogen fixation and growth of soybean and alfalfa. Agron. J. 58:201-203.

Binzel ML, Hess FD, Bressan RA, Hasegawa PM (1988) Intracellular compartmentation of ions in salt adapted tobacco cells. Plant Physiol. 86:607-614.

Bohnert HJ, Nelson DE, Jensen RG (1995) Adaptation to environmental stresses. Plant Cell 7:1099-1111.

Bradford MN (1976) A rapid and sensitive method for the quantitation of microgram quantities of protein utilizing the principle of protein-dye binding. Anal. Biochem. 72:248-254.

Campbell WH (1999) Nitrate reductase structure, function and regulation: bridging the gap between Biochemistry and Physiology. Annu. Rev. Plant Physiol. Mol. Biol. 50:277-303.

Cataldo DA, Haroon M, Schrader LE, Youngs VL (1975) Rapid colorimetric determination of nitrate in plant tissue by nitration of salicylic acid. Commun. Soil Sci. Plant Anal. 6:71-80. 
Cerezo M, Garcia-Agustin P, Serna MD, Primo-Millo (1997) Kinetics of nitrate uptake by Cytrus seedlings and inhibitory effects of salinity. Plant Sci. 126:105112.

Ciha AJ, Brun WA (1978) Effect of pod removal on nonstructural carbohydrate concentration in soybean tissue. Crop Sci. 18:773-776.

Cramer GR, Läuchli A, Polito VS (1985) Displacement of $\mathrm{Ca}^{2+}$ by $\mathrm{Na}^{+}$from the plasmalemma of root cells. A primary response to salt stress? Plant Physiol. 79:207277.

Dubois M, Gilles KA, Hamilton JK, Rebers PA, Smith F (1956) Colorimetric method for determination of sugars and related substances. Anal. Chem. 28:350-356.

Ebert G, Eberle J, Ali-Dinar H, Lüdders P (2002) Ameliorating effects of $\mathrm{Ca}\left(\mathrm{NO}_{3}\right)_{2}$ on growth, mineral uptake and photosynthesis of $\mathrm{NaCl}$-stressed guava seedlings (Psidium guajava L.). Scien. Hortic. 93:125135.

Feitosa de Lacerda C, Cambraia J, Oliva Cano MA, Ruiz HA (2001) Plant growth and solute accumulation and distribution in two sorghum genotypes under $\mathrm{NaCl}$ stress. Braz. J. Plant Physiol. 13:270-284.

Felker P, Lopez C, Soulier C, Ochoa J, Abdala R, Ewens M (2001) Genetic evaluation of Prosopis alba (algarrobo) in Argentina for cloning elite trees. Agrofor. Syst. 53:65-76.

Ferrario S, Valadier M, Foyer CH (1998) Over-expression of nitrate reductase in tobacco delays drought-induced decreases in nitrate reductase activity and mRNA. Plant Physiol. 117:293-302.

Flores P, Botella MA, Martínez V, Cerdá A (2002) Response to salinity of tomato seedlings with a splitroot system: nitrate uptake and reduction. J. Plant Nutr. 25:177-187.

Foyer CH, Valadier M, Migge A, Beeker TW (1998) Drought-induced effects on nitrate reductase activity and mRNA and on coordination of nitrogen and carbon in maize plants. Physiol. Plant. 117:283-292.

Frechill S, Lasa B, Ibarretxe L, Lamsfus C, Aparicio Trejo P (2001) Pea responses to saline stress is affected by the source of nitrogen nutrition (ammonium or nitrate). Plant Growth Regul. 35:171-179.

Gorham J, Wyn Jones RG, McDonell, E (1985) Some mechanisms of salt tolerance in crop plants. Plant Soil 89:15-40.

Gouia H, ghorbal MH, Touraine B (1994) Effects of $\mathrm{NaCl}$ on flows of $\mathrm{N}$ and mineral ions and $\mathrm{NO}_{3}{ }^{-}$reductase rate within whole plants of salt-sensitive bean and salttolerant cotton. Plant Physiol. 105:1407-1418.

Grieve CM, Grattan SR (1983) Rapid assay for determination of water-soluble quaternary-amino compounds. Plant Soil 70:303-307.
Hayashi H, Alia, Sakamoto A, Nonaka H, Chen THH, Murata N (1998) Enhanced germination under high-salt conditions of seeds of transgenic Arabidopsis with a bacterial gene $(\operatorname{cod} A)$ for choline oxidase. J. Plant Res. 111:357-362.

Heuer B (2003) Influence of exogenous application of proline and glycinebetaine on growth of salt-stressed tomato plants. Plant Sci. 165:693-699.

Hoagland, D.R. and D.I. Arnon. (1950) The water culture method for growing plants without soil. California Agricultural Experimental Station Circular, report 374.

Hsiao TC, Xu LK (2000) Sensitivity of growth of roots versus leaves to water stress: biophysical analysis and relation to water transport. J. Exp. Bot. 51:1595-1616.

Kant MG, Silverbusch M, Lips SH (1994) Physiological studies on salinity and nitrogen interaction in alfalfa. I. Biomass production and root development. J. Plant Nutr. 17:657-668.

Khan MA, Ungar IA, Showalter AM, Dewald HD (1998) $\mathrm{NaCl}$-induced accumulation of glycinebetaine in four subtropical halophytes from Pakistan. Physiol. Plant. 102: 487-492.

Klepper L, Flesher D, Hageman RH (1971) Generation of reduced Nicotinamide Adenine Dinucleotide for nitrate reduction in green leaves. Plant Physiol. 20:580-590.

Lauchli A, Epstein E (1990) Plant responses to saline and sodic conditions. In: Tanji KK (ed), Agricultural Salinity Assessment and Management, pp. 113-137. ASCE, New York.

Lutts S, Kinet JM, Bouharmont J (1996) Effects of salt stress on growth, mineral nutrition and proline accumulation in relation to osmotic adjustment in rice (Oryza sativa L.) cultivars differing in salinity resistance. Plant Growth Regul. 19:207-218.

Mansour MM (1998) Protection of plasma membrane of onion epidermal cells by glycinebetaine and proline against $\mathrm{NaCl}$ stress. Plant Physiol. Biochem. 35:767772.

Meloni DA, Oliva MA, Ruiz HA, Martinez CA (2001) Contribution of proline and inorganic solutes to osmotic adjustment in cotton under salt stress. J. Plant Nutr. 24:599-612.

Misra N, Dwiverdi, UN (1990) Nitrogen assimilation in germinating Phaseolus aureus under saline stress. J. Plant Physiol. 135:719-724.

Munns M (2002) Comparative physiology of salt and water stress. Plant Cell Environ. 25:230-250.

Nabil M, Coudert A (1995) Effects of sodium chloride on growth, tissue elasticity and solute adjustment in two Acacia nilotica subspecies. Physiol. Plant. 93:217-224.

Naidoo G, Naidoo Y (2001) Effects of salinity and nitrogen on growth, ion relations and proline accumulation in Triglochin bulbosa. Wetlands Ecol. Manag. 9:491-497. 
Rahman MS, Miyake H, Takeoka Y (2002) Effects of exogenous glycinebetaine on growth and ultrastructure of salt-stressed rice seedlings (Oryza sativa L.). Plant Prod. Sci. 5:33-44.

Rao KR, Gnaham A (1990) Inhibition of nitrate and nitrate reductase activity by salinity stress in Sorghum vulgare. Phytochemistry 29:1047-1049.

Rhodes D, Felker P (1987) Mass screening Prosopis (mesquite) seedlings for growth at seawater salinity. Forest. Ecol. Manag. 24:169-176.

Rhodes D, Hanson AD (1993) Quaternary ammonium and tertiary sulfonium compounds in higher plants. Ann. Rev. Plant Physiol. Mol. Biol. 44:357-384.

Rontein D, Basset G, Hanson AD (2002) Metabolic engineering of osmoprotectants accumulation in plants. Metab. Engineer. 4:49-56.

Sagi M, Savidov NA, L'Vov NP, Lips SH (1997) Nitrate Reductase and molybdenum cofactor in annual ryegrass as affected by salinity and nitrogen source. Physiol. Plant. 99:546-553.

Sakamoto A, Murata N (2001) The use of bacterial choline oxidase, a glycinebetaine-synthesizing enzyme, to create stress-resistant transgenic plants. Plant Physiol. 125: 180-188.
Sakamoto A, Murata N (2002) The role of glycine betaine in the protection of plants from stress: clues from transgenic plants. Plant Cell Environ. 25:163-171.

Saneoka H, Nagasaka C, Hahn DT, Yang WJ, Premachandra GS, Joly RJ, Rhodes D (1995) Salt tolerance of glycinebetaine-deficient and -containing maize lines. Plant Physiol. 107: 631-638.

Silveira JAG, Melo ARB, Viégas RA, Oliveira JTA (2001) Salinity-induced effects on nitrogen assimilation related to growth in cowpea plants. Environ. Exp. Bot. 46:171179.

Tanji KK (1990) Nature and extent of agricultural salinity. In: Tanji KK (ed), Agricultural Salinity Assessment and Management, pp. 1-13. ASCE, New York.

Velarde M, Felker P, Degano C (2003) Evaluation of Argentine and Peruvian Prosopis germplasm for growth at seawater salinities. J. Arid Environ. 55:515-531.

Viégas RA, Barreto de Melo AR, Gomes da Silveira JA (1999) Nitrate reductase activity and proline accumulation in cashew in response to $\mathrm{NaCl}$ salt shock. Rev. Bras. Fisiol. Veg. 11:21-28.

Yeo A (1998) Molecular biology of salt tolerance in the context of whole-plant physiology. J. Exp. Bot. 49:915-929. 